\begin{tabular}{c} 
journal homepage: http://ijiemjournal.uns.ac.rs/ \\
International Journal of Industrial \\
Engineering and Management \\
Volume $12 / \mathrm{No} 3 /$ September $2021 / 216-225$ \\
\hline
\end{tabular}

Original research article

\title{
Analyzing the effect of supply chain strategies and collaboration on performance improvement using MIMIC model
}

\author{
S. Kunnapapdeelert *, K. Pitchayadejanant \\ Burapha University, International College, Logistics Management, Chonburi, Thailand;
}

\begin{abstract}
The supply chain strategies, lean and agile, are widely discussed in Thai manufacturers. This study investigates the impact of supply chain strategies on integrations and the effect of supply chain integrations on operational performance. Multiple indicator multiple cause model is used for analyzing the data gathered from Thai manufacturers. The results indicated that supply chain strategies are positively associated with all supply chain integrations (supplier integration, customer integration, and internal integration), and internal integration positively impacts operational performance. Also, Thai manufacturers must provide excellent internal integration inside the organization to enhance the integration between suppliers and customers.
\end{abstract}

\section{ARTICLE INFO}

Article history:

Received April 25, 2021

Revised July 17, 2021

Accepted July 27, 2021

Published online September 10, 2021

Keywords:

Lean;

Agile;

Supply chain integrations;

Operational performance;

MIMIC model;

* Corresponding author: Siwaporn Kunnapapdeelert siwapornk@go.buu.ac.th

\section{Introduction}

Today's supply chain management has become more complex with economics and market dynamics which the organization needs to respond to the fierce business situation. Various supply chain strategies have been designed and adapted to support the business thrive. However, the reduction of costs and wastes, including quickly responding to the market and customer, is one of the most necessary for business success in competitive situations of this era. The agile enterprise appears to be the winning strategy in the digital era. The agile concept can enhance companies as leaders in a competitive market with volatile customer requirements [1]. According to the literature, the implementation of lean and agile in supply chain strategy seems to be a successful solution in the 21 st century. Lean is a managerial philosophy that can support the organization to investigate the supply chain processes by eliminating non-value-added operations and actions in the process. Lean originated from the Toyota Production System (TPS), which is called Just-in-Time (JIT). It relies on the concept of waste minimization to enhance supply chains to overcome inefficiencies and reduce waste. It focuses on determining inefficiencies of activities in the supply chain process and eliminating such efficiencies activities to improve the organization's performance [2]. 
Most of the successful companies are the companies that link their internal improvement process with their external suppliers and customers. Subsequently, lean supply chain management can be explained as organizations that connect the physical, information, and financial flow from upstream to downstream. These flows work collaboratively to reduce cost and waste to satisfy each customer's needs [3].

In the agile approach, it has been considered an essential aspect of the manufacturing system. Agility delivers value to customers, is ready for change, values human knowledge and skills, and forms virtual partnerships [4]. Agile supply chain involves the responsibility and adaptability to satisfy customer requirements while avoiding the risk of supply chain disruption [5]. The firm can promptly respond to the short-term temporary changes in the supply chain. This concept emphasizes the collaboration with customers and the adaption to change of people, technology, and process in the supply chain [6]. Implementing both lean and agile strategies requires both internal and external collaboration in the supply chain, which would enhance the operational performance of all partners in the supply chain.

The purposes of this work are to examine the relationship between supply chain strategy and supply chain collaboration strategy and their impact on operational performance in the supply chain of the organization. The literature review found that supply chain strategies such as lean and agile are affected to the supply chain performance [7]. Further, it was found that external (supplier and customer) integration and internal integration influenced the operational performance as well [8-9].

Relationships between supply chain strategies and supply chain collaboration, including their impact on operational performance in the supply chain, are examined in this work. Exploratory Factor Analysis (EFA), Confirmatory Factor Analysis (CFA), and MIMIC model are applied to analyze surveyed data from senior and executive management members in the purchasing/materials management/ logistics/ supply chain functions from Thailand industries. Such a model has been successfully proven to provide rigorous results in most experiments and research.

This work would provide the theoretical understanding and empirical support of how supply chain strategies and integration strategies can work together to boost supply chain performance, especially in Thailand.

\section{Theoretical Background and Hypotheses Development}

Several researchers have discussed the different ideas of supply chain strategies and supply chain collaboration to enhance the operational performance in the organization's supply chain, as presented in Table1.

\subsection{The effect of supply chain strategies (SCSs) on supply chain integration (SCI)}

Agile strategy is the organizational direction and commitment towards effective and quick response to customer requirement change. Researchers explained agility as the collaboration among suppliers, customers, and manufacturers [16]. The selection of appropriate suppliers has been considered as an essential function for the firm's success. It was suggested that the ability to rapidly respond to the change

Table 1. Theoretical background results

\begin{tabular}{|c|c|c|c|c|c|}
\hline Themes & Method & Model & Year & Journal & References \\
\hline $\begin{array}{l}\text { Relationship of lean and operational } \\
\text { performance }\end{array}$ & $\begin{array}{l}\text { Systematic } \\
\text { literature }\end{array}$ & - & 2021 & CJMST & [10] \\
\hline $\begin{array}{l}\text { Relationship of agility and operational } \\
\text { performance }\end{array}$ & Survey & SEM & 2020 & ORP & [11] \\
\hline $\begin{array}{l}\text { Relationship of Lean and agility on } \\
\text { operational performance }\end{array}$ & Survey & PLS-SEM & 2020 & EMJ & [12] \\
\hline \multirow{4}{*}{$\begin{array}{l}\text { Relationship of supply chain integra- } \\
\text { tion on operational performance }\end{array}$} & Survey & SEM & 2012 & IJPE & [8] \\
\hline & Survey & SEM & 2014 & IJPE & [13] \\
\hline & Survey & SEM & 2020 & IJPE & [14] \\
\hline & Survey & CB-SEM & 2021 & IMM & [15] \\
\hline
\end{tabular}

CJMST: CIRP Journal of Manufacturing Science and Technology; ORP: Operations Research; Perspectives;

EMJ: European Management Journal; IJPE: International Journal of Production Economics;

IMM Industrial Marketing Manage 
in both quantity and variety of the product become one of the essential criteria for supplier selection and evaluation [17]. An agile supply chain enhances the collaboration among suppliers and manufacturers to increase the ability of both parties to create values and detect the change of demand quickly.

Lean supply chain strategy employs continuous improvement efforts that emphasize waste and non-value-added activities elimination through the supply chain. This concept is very effective when demand is relatively stable, predictable and the variety of the product is low [18-19]. Supplier integration involves the business integration among suppliers and manufacturers through information technology applications. It concerns the planning system of purchasing, production, and logistics. Various researchers proposed that supplier integration is one of the vital criteria for selecting suppliers [20-23]. Thus, it confirms that lean manufacturers should have good relationships with the suppliers. Manufacturers can ensure that the required raw materials are available for the JIT manufacturing system. In the current business competitive situation, all organizations must manage various cases to develop and maintain their business. Therefore, the following hypothesis is proposed:

Hypothesis 1 Supply chain strategies (SCSs) have a positive impact on supplier integration.

Agility is explained as managing speed, flexibility, innovation, and quality to provide customer-oriented products and services in a rapidly changing environment [24]. Nowadays, customers have become a vital source of knowledge for firms. It is because customers have gained a lot of knowledge and experiences about the products and services that they are using. This information is considered a new competitive advantage for firms [25]. Customer integration can boost supply chain agility by developing quick observation (while sharing information with the partner) and responding to market and customer demand. Researchers revealed that customer involvement is vital for agile implementation [26]. Consequently, customers should share their technology, knowledge, innovation, demand, and related information with the manufacturers to adapt themselves to serve customers' needs.

Lean principles such as waste elimination and continuous improvement seem to be never-ending activities [27]. It is a long-term improvement that might require years to complete the whole system. Development of industry 4.0 requires value, value stream, flow, pull, perfection, and people and teamwork from the principle of lean production [28]. The value must always be obtained from the customer's point of view. The value stream is composed of all processes needed to produce the product, from customer order to delivery. Flow relies on customer orientation by reducing the lead time. Pull principle links to the customer order that triggers the production process while perfection and people, and teamwork are the cooperation of all employees. The priority in the lean concept is customer satisfaction. Subsequently, the focus on customer orientation and customer collaboration is essential. Hence, the following hypothesis is developed.

Hypothesis 2 Supply chain strategies (SCSs) have a positive impact on customer integration.

Agile strategy emphasis market sensitivity and prompt response to the customer. To achieve this concept, all functions within the organization should be integrated to perform process coordination among different functions [29]. Internal integration is another supply chain integration that extends to the organization that links the practical activities of internal functional units to perform mutual collaboration and synchronization to satisfy customer requirements. Each unit in the organization shares data about demand forecasting, inventories, and production plans via management information systems (MIS). The agile supply chain merges all internal functions in the organization to satisfy customers' needs. It also enhances the organization to be able to mitigate problems, mistakes, and conflict effectively.

Previously, it was stated that perfection and people, and teamwork depend on the cooperation of all employees [27]. Employees need to understand the standard of their works with transparent processes to produce the perfect workpieces for the customers. In people and teamwork, lean philosophy focuses on collaboration, so the organization should respect the employees. It means that all functions in the organization should have a solid integration to drive the organization to be successful based on a lean supply chain strategy. Hence, the following hypothesis is expressed.

Hypothesis 3 Supply chain strategies (SCSs) has a positive impact on internal integration.

\subsubsection{The effective supply chain integration (SCI) on operational performance}

Supplier integration is the collaboration between the manufacturer and its suppliers [29]. Good collaboration and relationships will help manage inter-organizational upstream activities by sharing related infor- 
mation and making some decisions. The common goal of supplier integration is to perform collaborative planning and forecasting demand to reduce the supply risk, inventory, time, and costs. Several research papers found that sharing information with suppliers or making decisions with each other provides better operational performance in terms of cost, delivery, product quality, and flexibility [13, 29-31].

For gaining competitive advantages, the organization must have the measurement to measure the performance intensely. The measurement must be specific, measurable, assignable, realistic, and time-related. Operational performance is multidimensionally measured rather than solely measured in cost, quality, delivery, and flexibility [9]. The enhancement of supplier integration will foster operational performance improvement: cost, delivery, product quality, and flexibility [32]. Thus, the following hypothesis is considered.

Hypothesis 4 Supplier integration has a positive impact on operational performance

Supplier integration and customer integration are considered external integration. Customer integration is the collaboration between the manufacturer and its customer to operate downstream. It is the management of inter-organizational activities that allows organizations to apply some information and resources from customers into the processes and decisions of the organization. Customer integration helps the organization to have more understanding about the market needs [32]. It helps to enhance the accuracy of the product information, reduce error, and reworking. This would lead to better adoption in production plans which results in better operational performance. The hypothesis is set as:

Hypothesis 5 Customer integration has a positive impact on operational performance

Internal integration can be explained as a cross-functional strategy that associates with collaborative procurement, product design, manufacturing, warehousing, marketing, and distribution for satisfying customer's needs [33-34]. Information sharing and collaboration among functions in the organization enhances the organization to joint decision-making. It can improve the capability of the organization in processing available information. An effective collaboration would help to reduce inventory, errors, reworks, speed of each activity. This can reduce production cycle time, cost while improving flexibility [35]. Therefore, the following hypothesis is proposed.

Hypothesis 6 Internal integration has a positive impact on operational performance

The conceptual framework with the proposed hypotheses is presented in Figure 1.

The outline for this work is organized as follows. The research methodology of the study is described in section 3. Sections 4 and 5 present results and discussion of the study. Lastly, conclusions, limitations including future research, are recommended in section 6 .

\section{Research Methodology}

This work aims to examine the effect of supply chain strategies and supply chain integration on operational performance improvement. The data was

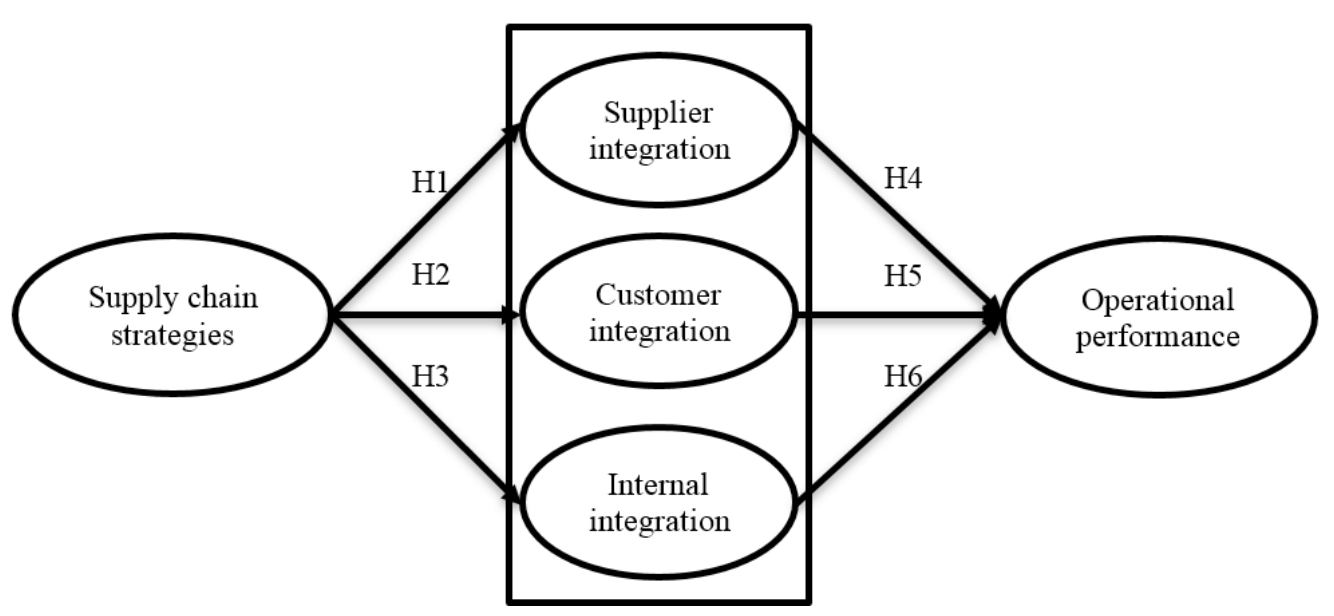

Figure 1. Proposed model and hypotheses 
collected from manufacturers in Thailand. Manufactures were purposely sampled in major provinces from five regions of Thailand. Four hundred questionnaires were distributed. Each target company was first contacted by email and telephone to explain the scope and purpose of the study. Most of the respondents work in high management levels such as senior engineer, production manager, quality control manager, procurement manager, sales manager, and logistics manager. A five-point Likert scale (ranging from $1=$ strongly disagree to $5=$ strongly agree) is used for measuring all indicators. Respondents were asked to indicate their agreement with the supply chain strategies of their organization to measure agile and lean supply chain strategies. Supply chain integration practices questions related to data integration, collaborative planning, real-time integration, and integrative systems were used for measuring both internal and external integration. Lastly, operational performance related to cost, quality, delivery, and flexibility are then measured. Three items, including manufactured cost, productivity, and capacity utilization, were used for measuring cost strategy. Three items related to product conformance quality, Durability, and reliability of the product were used to measure quality strategy. Two items involved with delivery reliability and delivery lead time were adopted to measure delivery strategy. Lastly, the flexibility strategy was measured by new product introduction, product mix, and line change. According to the collected data, it found that there was missing data in two questionnaires. Therefore, there are a total of 398 usable responses. $51.26 \%$ of respondents were male (204). The majority of the respondents are working in the central (34.92\%), eastern (25.88\%), and northeastern (20.86\%) regions of Thailand. The others are $6.03 \%$ from western, $6.78 \%$ from southern, and $5.53 \%$ from northern Thailand. The latter part of the survey is seeking the opinion regarding the affecting factors to the organization's operational performance. A five-point Likert scale was used to rate each statement of the model. Score 1 indicates strongly disagree, whereas score 5 indicates strongly agree with the statement.

\section{Results}

\subsection{Reliability and validity measurement}

Exploratory factor analysis (EFA) was used to detect the underlying dimensions. It was performed by using the maximum likelihood estimation via vari- max rotation. The result presents the factor loading, reliability analysis, average variance extracted, and composite reliability that are used to explain how much the instrument is the consistent response from the respondent. The computational results showed that all values of Cronbach's alpha in this study exceed 0.80 which achieves valid reliability [36]. To measure the convergent validity, composite reliability $(\mathrm{CR})$ and the average variance extracted (AVE) are considered. In general, CR is greater than 0.6 and AVE is greater than 0.5, indicating that the reliability of the model is good [37]. The KMO value is 0.885 which is more than 0.70 and Bartlett's test value is less than 0.50. These confirm that the collected data is enough for making the factor analysis. The results from factor analysis are illustrated in Table 2.

\subsection{Measurement model}

The hypothesized causal variables in the MIMIC model were tested by using AMOS SPSS.

The confirmatory factor analysis (CFA) was suggested to be conducted before the MIMIC model analysis is performed. CFA should be applied to examine the convergent and discriminant validity. In this work, seven fit indices from thirty absolute items are used for assessing the goodness of fit for the model as described in Table 3.

The results in Table 3 show a good fit of the observed data. MIMIC model analysis was applied to determine the hypothesis relationship of the proposed model. The values of fit indices from the analysis are acceptable. This confirmed that the obtained results are reliable.

\subsection{Structural model}

The relationship and significant effect of supply chain strategies (agile and lean) on supply chain integrations (supplier integration, customer integration, and internal integration) coupled with the relationship and significant effect of such supply chain integration on operational performance were then examined as presented in Table 4. Path coefficients are shown in Figure 2.

\section{Discussion}

To measure the efficiency of a system, it is necesMIMIC model analysis with the concept of structural equation model (SEM) was applied to test the hypothesis relationship of the proposed model. H1 
Table 2. Factor structures by exploratory factor analysis and reliability

\begin{tabular}{|c|c|c|c|c|c|}
\hline \multicolumn{2}{|c|}{ VARIABLE } & $\begin{array}{l}\text { Factor } \\
\text { Loading }\end{array}$ & $\begin{array}{l}\text { Cronbach's } \\
\text { Alpha }\end{array}$ & $\begin{array}{l}\text { Average Variance } \\
\text { Extracted (AVE) }\end{array}$ & $\begin{array}{l}\text { Composite } \\
\text { Reliability (CR) }\end{array}$ \\
\hline \multicolumn{6}{|c|}{ OPERATIONAL PERFORMANCE (OP) } \\
\hline \multirow{10}{*}{$\mathrm{OP}$} & D1 Delivery speed & .837 & \multirow{4}{*}{0.860} & \multirow{4}{*}{0.663} & \multirow{4}{*}{0.914} \\
\hline & D2 Delivery reliability & .828 & & & \\
\hline & D3 On time delivery & .778 & & & \\
\hline & Q2 Product quality and reliability & .819 & & & \\
\hline & Q3 Durability of the product & .799 & \multirow[t]{2}{*}{0.860} & \multirow[t]{2}{*}{0.621} & \multirow[t]{2}{*}{0.898} \\
\hline & Q1 Conformance quality & .745 & & & \\
\hline & F1 Flexible to change volume & .823 & \multirow{2}{*}{0.808} & \multirow{2}{*}{0.668} & \multirow{2}{*}{0.879} \\
\hline & F2 Flexible to change product mix & .812 & & & \\
\hline & C1 Unit manufacturing cost & .834 & \multirow{2}{*}{0.798} & \multirow{2}{*}{0.686} & \multirow{2}{*}{0.888} \\
\hline & C2 Ordering cost & .822 & & & \\
\hline \multicolumn{6}{|c|}{ SUPPLIER INTEGRATION (SI) } \\
\hline \multirow{6}{*}{$\mathrm{SI}$} & $\begin{array}{l}\text { 2. The establishment of quick ordering systems with our major } \\
\text { supplier. }\end{array}$ & .791 & & & \\
\hline & 4. Stable procurement through network with our major supplier. & .757 & & & \\
\hline & 6. Our major supplier shares available inventory with us. & .751 & & & \\
\hline & 3. The level of strategic partnership with our major supplier. & .731 & & & \\
\hline & $\begin{array}{l}\text { 1. The level of information exchange with our major supplier } \\
\text { through information networks. }\end{array}$ & .729 & & & \\
\hline & $\begin{array}{l}\text { 5. The participation level of our major supplier in the process of } \\
\text { procurement and production. }\end{array}$ & .745 & & & \\
\hline \multicolumn{6}{|c|}{ CUSTOMER INTEGRATION (CI) } \\
\hline \multirow{5}{*}{$\mathrm{Cl}$} & 6. Follow-up with our major customer for feedback. & .802 & \multirow{5}{*}{0.870} & \multirow{5}{*}{0.577} & \multirow{5}{*}{0.923} \\
\hline & $\begin{array}{l}\text { 5. The establishment of quick ordering systems with our major } \\
\text { customer. }\end{array}$ & .771 & & & \\
\hline & $\begin{array}{l}\text { 3. The level of sharing of market information from our major cus- } \\
\text { tomer. }\end{array}$ & .758 & & & \\
\hline & $\begin{array}{l}\text { 1. The level of linkage with our major customers through informa- } \\
\text { tion networks. }\end{array}$ & .733 & & & \\
\hline & 2. The level of computerization for our major customer's ordering. & .732 & & & \\
\hline \multicolumn{6}{|c|}{ SUPPLY CHAIN STRATEGIES (SCS) } \\
\hline \multirow{5}{*}{ SCS } & LSC6: Your company inspects product frequently & .830 & \multirow{5}{*}{0.861} & \multirow{5}{*}{0.593} & \multirow{5}{*}{0.928} \\
\hline & $\begin{array}{l}\text { ASC1: Your company responds effectively to changing requirements } \\
\text { of design }\end{array}$ & .782 & & & \\
\hline & LSC3: Your company reduces any kind of waste & .767 & & & \\
\hline & LSC2: Your company provides standardized product & .741 & & & \\
\hline & $\begin{array}{l}\text { ASC2: Your company responses quickly to customization require- } \\
\text { ments }\end{array}$ & .728 & & & \\
\hline \multicolumn{6}{|c|}{ INTERNAL INTEGRATION (II) } \\
\hline & 1. Data integration among internal functions. & .757 & & & \\
\hline$\|$ & 2. Enterprise application integration among internal functions. & .747 & 0874 & 0554 & 0897 \\
\hline 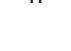 & 4. Real-time searching of the level of inventory. & .741 & & & \\
\hline & 3. Integrative inventory management. & .732 & & & \\
\hline
\end{tabular}

Note: $\mathrm{OP}$ = Operational performance (quality, delivery, flexibility, cost), $\mathrm{SI}=$ Supplier integration, $\mathrm{Cl}$ = Customer integration, $\mathrm{SCS}$ = Supply chain strategies (agility and lean), II = Internal integration. 
proposed a positive relationship between supply chain strategies and supplier integration. Hypothesis $\mathrm{H} 1$ is significant with the estimate value of 0.443 (p-value $<0.01)$ and standardized estimation $=0.389$. This indicates that supply chain strategies are positively related to supplier integration. The use of lean strategy requires high supplier capability in terms of information sharing, quality, and JIT delivery. Considering agility strategy emphasizes a quick response to the customer requirement. Consequently, sharing information about the quick-change situation should be shared with the supplier. H2 showed a positive relationship between supply chain strategies and customer integration. Hypothesis H2 was supported because it is significant with the estimated value of 0.415 (p-value $<0.01)$ and standardized estimation $=$ 0.341 . This confirms that supply chain strategies re- quire sharing updated information with the customer. The positive relationship between supply chain strategies and internal integration (H3) was also supported. Hypothesis $\mathrm{H} 3$ is significant with the estimate value of 0.459 (p-value <0.01) and standardized estimation $=0.401$. It can be explained that the need for internal integration for supply chain strategies is more important than external integrations (supplier and customer integrations). According to the strength and significance of the direct effect of supply chain strategies (agile and lean) on a supplier, customer, and internal integrations, it confirmed that the positive relationship of supply chain strategies and supply chain integration are statically significant.

Next, the relationship between supply chain integrations and operational performance is examined. Hypothesis $\mathrm{H} 4$ and hypothesis $\mathrm{H} 5$ are the tests of

Table 3. Five fit indices were used for assessing the goodness of fit

\begin{tabular}{|c|c|c|c|}
\hline Indexes & Model Fit Summary & Acceptable Criteria & References \\
\hline Chi-square/DF (CMIN/DF) & 1.878 & Less than 2 & {$[38]$} \\
\hline Normed fit index (NFI) & 0.958 & more than 0.90 & {$[38-40]$} \\
\hline Comparative fit index (CFI) & 0.980 & more than 0.90 & [38] \\
\hline Goodness of fit index (GFI) & 0.971 & more than 0.90 & [38] \\
\hline Adjusted GFI (AGFI) & 0.924 & more than 0.90 & {$[41]$} \\
\hline Standardized RMR (SRMR) & 0.032 & $\begin{array}{l}\text { less than } 0.05 \text { good fit, and } \\
\text { less than } 0.08 \text { acceptable fit }\end{array}$ & [38] \\
\hline $\begin{array}{l}\text { Root mean square error of } \\
\text { approximation (RMSEA) }\end{array}$ & 0.066 & $\begin{array}{l}\text { less than } 0.05 \text { good fit, less } \\
\text { than } 0.08 \text { acceptable fit }\end{array}$ & [42-43] \\
\hline
\end{tabular}

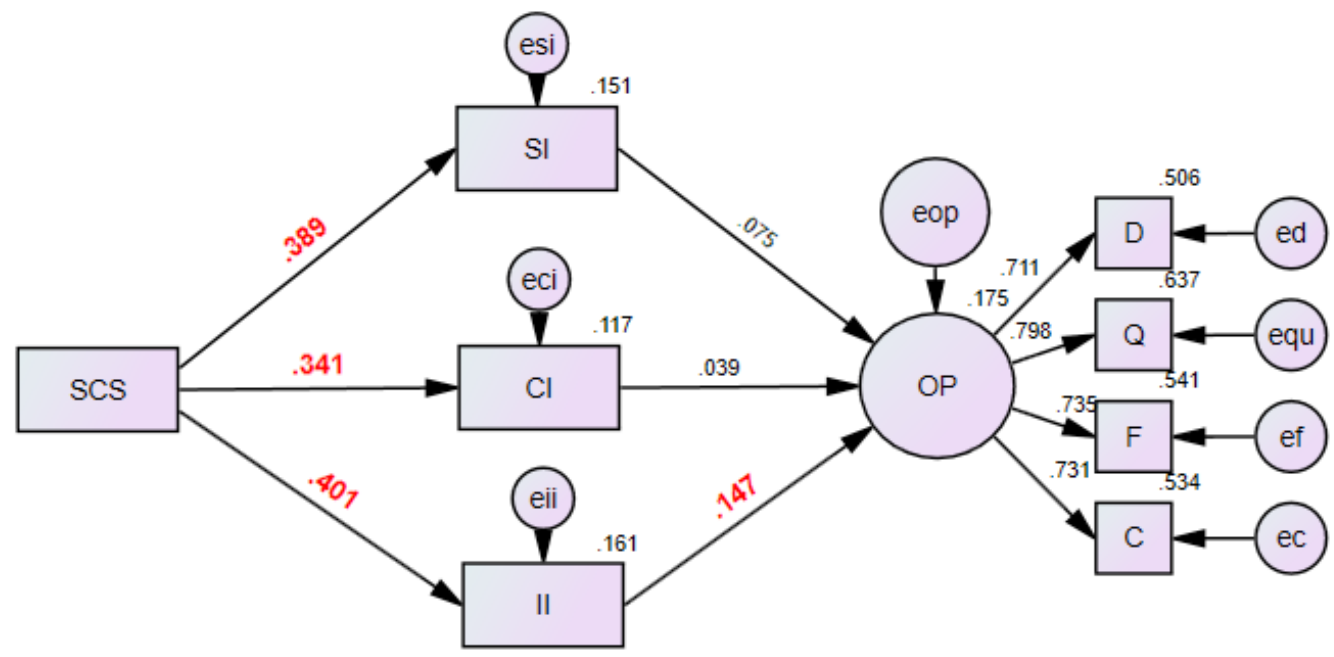

Figure 2. Standardized Estimation of MIMIC Model Analysis 
the relationship between external integration (supplier and customer integrations) with operational performance. It found that they have an insignificant direct impact on operational performance. The estimated values are 0.054 and 0.026 which both p-values are higher than 0.05. Lastly, hypothesis H6 confirms that internal integration is positively related to operational performance with the estimated value is 0.105 (p-value $<0.05)$ and standardized estimation $=$ 0.147 . This can be explained that the collaboration within the organization can enhance the operational performance of the organization in terms of delivery, quality, cost, and flexibility. In other words, the results reveal the accepted hypotheses test $(\mathrm{H} 1, \mathrm{H} 2$, H3, and H6). The other two hypotheses (H4 and H5) were insignificant in the current study.

\section{Conclusions}

The paper providing theoretical understanding and empirical support of how supply chain strategies and integration strategies can work together to enhance supply chain performance. The paper also develops and validates instruments for measuring two types of supply chain strategies and integration strategies by a statistical approach.

Supply chain strategies (lean and agile) were proven to be a significant factor of supply chain integrations consisting of supplier integration, internal integration, and customer integration. In Thailand, the supply chain strategies also drive the integration for both internal and external (supplier and customer) of organizations which is similar to China [8]. SCSs require a relationship with both suppliers and customers to design the supply chain structure and enhance fleeting market opportunities.

However, SCSs require internal integration for synchronizing all internal activities between differ- ent functions and responsive to the change. Also, excellent internal integration leads the improvement in operational performance. The results presented that internal integration is positively related to operational performance. This confirms that the internal integration enables information and knowledge sharing across functions. This can internally improve the process and product designs as a results product quality, delivery performance, cost efficiency, and flexibility are enhanced.

According to the study, supplier integration and customer integration do not significantly impact operational performance. Supplier integration and customer integration had positive effects on new product performance [16]. External integration is necessary when the organization is novel in the market. It implies, for the newcomers in the supply chain, that they need to deal closely with suppliers and customers and integrate them with the organization. In addition, the effects of supplier integration and customer integration toward operational performance vary according to the kind of production: customized production, batch production, or mass production [19]. This implies that the organization requires more integration with suppliers and customers when the target customers need the customized products. The company needs data and information to handle operational performance. If the company focuses on mass production, the level of integration between supplier and customer is well set up in the system. Internal integration plays a key role to enhance external integration [21]. Therefore, the company needs to focus more on internal integration to synchronize the supplier and customer and also improve operational performance.

There are some limitations in this research that would be considered in future studies. Firstly, the duration of the establishment of the company can

Table 4. Hypothesis testing of the proposed model

\begin{tabular}{llllll}
\hline Hypothesis & Causal Effects & $\begin{array}{l}\text { Unstandardized } \\
\text { Estimation }\end{array}$ & S.E. & $\begin{array}{l}\text { Standardized Esti- } \\
\text { mation }\end{array}$ & Sig. \\
\hline $\mathrm{H} 1$ & $\mathrm{SCS} \rightarrow \mathrm{SI}$ & 0.443 & 0.074 & 0.389 & $* * *$ \\
$\mathrm{H} 2$ & $\mathrm{SCS} \rightarrow \mathrm{Cl}$ & 0.415 & 0.080 & 0.341 & $* * *$ \\
$\mathrm{H} 3$ & $\mathrm{SCS} \rightarrow \mathrm{II}$ & 0.459 & 0.074 & 0.401 & $* * *$ \\
$\mathrm{H} 4$ & $\mathrm{SI} \rightarrow \mathrm{OP}$ & 0.054 & 0.055 & 0.075 & 0.282 \\
$\mathrm{H} 5$ & $\mathrm{Cl} \rightarrow$ OP & 0.026 & 0.050 & 0.039 & 0.569 \\
$\mathrm{H} 6$ & $\mathrm{II} \rightarrow$ OP & 0.105 & 0.054 & 0.147 & $0.034^{* *}$ \\
\hline
\end{tabular}

Note: $* * *$ is 0.01 of significance level $* *$ is 0.05 of significance level 
be the moderator to classify the level of external integration towards operational performance. Secondly, with the review by researchers, lean and agile are mostly mentioned among logisticians in Thailand. The other supply chain strategies could be extended in further work which can be compared to the efficiency of operational performance with this study. Thirdly, the effect of internal integration on external integration is discarded in the study, in future work, the researcher can study to test the statement: internal integration plays the key role to enhance external integration [21]. Future studies can also examine the supply risk management practice for the success of supply chain integration. Lastly, the future study might be extended by including the factors related to green and sustainable supply chain management.

\section{Funding}

This work was fully supported by the Burapha University International College to provide recommendations that helped improve this study and grant financial support.

\section{References}

[1] C. K., Udokporo, A., Anosike, M., Lim, S. P., Nadeem, J. A., Garza-Reyes, \& C. P., Ogbuka, "Impact of Lean, Agile and Green (LAG) on business competitiveness: An empirical study of fast moving consumer goods businesses", Res., Conservation and Recycling, vol. 156, 2020, pp. 1-10.

[2] J. J., Mistry, "Supply Chain Manage. : A Case Study of an Integrated Lean and Agile Model," Qualitative Res. in Accounting \& Manage. , vol. 2, no. 2, 2005, pp.193-215.

[3] K. L., VITASEK, K. B., Manrodt, and J., Abbott, "What makes a lean supply chain?" Supply Chain Manage. Rev., vol. 9, no. 7, pp. 39-45: ill., Oct. 2005 .

[4] S. L., Goldman, R. N., Nagel, and K., Preiss, Agile competitors, and virtual organizations: strategies for enriching the customer. vol. 8, New York: Van Nostrand Reinhold, 1995.

[5] H. L., Lee, "The triple-A supply chain," Harvard Bus. Rev., vol. 82, no. 10, 2004, pp. 102-113.

[6] P., Serrador, and J. K. Pinto, "Does Agile work?-A quantitative analysis of agile project success," Int. J. of Project Manage. , vol. 33, no. 5, pp.1040-1051.

[7] S., Qrunfleh, and M., Tarafdar, "Supply chain Inf. Syst. strategy: Impacts on supply chain performance and firm performance,". Int. J. of Prod. Econ., vol. 147, pp.340-350, Jan. 2014.

[8] D., Prajogo, and J., Olhager, "Supply chain integration and performance: The effects of long-term relationships, Inf. Technol. and sharing, and logistics integration," Int. J.of Prod. Econ., vol. 135, no. 1, 2012, pp. 514-522.

[9] Y., Qi, B., Huo, Z., Wang, and H. Y. J. Yeung, "The impact of operations and supply chain strategies on integration and performance," Int. J.of Prod. Econ., vol. 185, 2017, pp. 162-174.

[10] N., Garcia-Buendia, J., Moyano-Fuentes, and J.M., Maqueira-Marín, "Lean supply chain management and performance relationships: what has been done and what is left to do," CIRP J. of Manuf. Science and Technology, vol. 32, 2021. pp.405-423.

[11] R., El-Khalil, andA.M. Mohamad, "The mediating impact of sustainability on the relationship between agility and operational performance," Operations Research Perspectives, vol. 7, 2020, pp. 100171.

[12] M., Srinivasan, S., Prashant and N.I., Karthik, "Response strategy to environment context factors using a lean and agile approach: Implications for firm performance," European Manage. J., vol. 38, no. 6, 2020, pp. 900-913.

[13] Y., He, K. K., Lai, H., Sun, and Y. Chen, "The impact of supplier integration on customer integration and new product performance: The mediating role of Manufacturing flexibility under trust theory," Int. J.of Prod. Econ., vol. 147, pp. 260-270, Jan. 2014.

[14] Munir, M., Jajja, M.S.S., Chatha, K.A. and Farooq, S., 2020. Supply chain risk management and operational performance: The enabling role of supply chain integration. Int. J.of Prod. Econ, vol. 227, p.107667.

[15] Liu, A., Liu, H. and Gu, J., 2021. Linking business model design and operational performance: The mediating role of supply chain integration. Ind. Marketing Manage., vol. 96, pp.60-70.

[16] M. J., Braunscheidel, and N. C., Suresh, "The organizational antecedents of a firm's supply chain agility for risk mitigation and response," J. of Operations Manage. , vol. 27, no. 2, 2009, pp. 119-140.

[17] H., Chiub, and Y. H., Tsenga, "Agility evaluation using fuzzy logic," Int. J. Prod. Econ., vol. 101, 2006, pp. 353-368.

[18] D., Birhanu, K., Lanka, A. N., Rao, "A survey of classifications in supply chain strategies," Procedia eng. vol. 97, pp. 2289-2297, Jan. 2014.

[19] S. A. Villacís and P. S. Burneo, "UAVs' efficient assembly: Lean Manufacturing implementation in an UAVs' Assembly Company," Int. J. Ind. Eng. Manag., vol. 11, no. 4, pp. 237-252, 2020, doi: 10.24867/IJIEM-2020-4-268.

[20] D. J., Bowersox, D. J., Closs, and T. P., Stank, 21st century logistics: making supply chain integration a reality, 1999.

[21] C. G. Chatzopoulos and M. Weber, "Digitization and Lean Customer Experience Management: Success Factors and Conditions, Pitfalls And Failures," Int. J. Ind. Eng. Manag., vol. 12, no. 2, pp. 73-84, 2021, doi: 10.24867/IJIEM-2021-2-278.

[22] H., Taherdoost, and A., Brard, "Analyzing the process of supplier selection criteria and methods," Procedia Manuf., vol. 32, 2019, pp. 1024-1034.

[23] M., Cho, M. A., Bonn, L., Giunipero, and J. S., Jaggi, "Supplier selection and partnerships: Effects upon restaurant operational and strategic benefits and performance," Int. J.of Hospitality Manage. , vol. 94, pp. 102781, Apri. 2021.

[24] P. Y., Huang, B., Niu, and S. L., Pan, "Platform-based customer agility: An integrated framework of Inf. Manage. structure, capability, and culture," Int. J.of Inf. Manage. , vol. 59, pp. 102346, Aug. 2021.

[25] M., Zielske, and T. Held, "Application of agile methods in traditional logistics companies and logistics startups: Results from a German Delphi Study,"J. of Syst. and Softw., pp. 110950, Mar. 2021

[26] R., Hoda, J., Noble, and S., Marshall, "The impact of inadequate customer collaboration on self-organizing Agile teams," Inf. and Softw. Technol., vol. 53, no. 5, pp. 521-534, May 2011.

[27] J. G., Schmidt, and D. Lyle, "Lean integration: an integration factory approach to Bus. agility," Pearson Education., May 2020.

[28] H., Bauer, F., Brandl, C., Lock, and G. Reinhart, "Integration of Industrie 4.0 in lean Manuf. learning 
factories," Procedia Manuf., vol. 23, pp. 147-152., Jan. 2018.

[29] J., Roh, P., Hong, and H. Min, "Implementation of a responsive supply chain strategy in global complexity: The case of manufacturing firms," Int. J.of Prod. Econ., vol. 147, pp. 198-210, Jan. 2014.

[30] J., Wang, and W. Zhuo, "Strategic Inf. sharing in a supply chain under potential supplier encroachment," Computers \& Ind. Eng., vol. 150, pp. 106880, Dec. 2020.

[31] C. J. Yuik and P. Puvanasvaran, "Development of Lean Manufacturing Implementation Framework in Machinery and Equipment SMEs,” Int. J. Ind. Eng. Manag., vol. 11, no. 3, pp. 157-169, 2020, doi: 10.24867/IJIEM-2020-3-261..

[32] Y., Shou, Y., Li, Y., Park, and M., Kang, "Supply chain integration and operational performance: the contingency effects of production System," J. of Purchasing and Supply Manage., vol, 24, no.4, pp. 352-360, Oct. 2018.

[33] E. A., Morash, C., Dröge, and S., Vickery, "Boundary spanning interfaces between logistics, production, marketing and new product development," Int. J.of Physical Distribution \& Logistics Manage., Oct. 1996.

[34] I., de la Calle, A., Freije, and J. V., Ugarte, "Role of supply chain integration in the product innovation capability of servitized Manuf. companies," Technovation, pp. 102216, Jan. 2021.

[35] B. B., Flynn, X., Koufteros, and G., Lu, "On theory in supply chain uncertainty and its implications for supply chain integration," J. of Supply Chain Manage. , vol. 52, no. 3, pp. 3-27. Jul. 2016.

[36] J. C., Nunnally, "Psychometric theory 3E," Tata McGraw-hill education, 1994.

[37]J. C., Anderson, and D. W., Gerbing, "Structural equation modeling in practice: A Rev. and recommended two-step approach," Psychological bulletin, vol. 103, no. 3, pp. 411, May. 1988.

[38] L. T., Hu, and P. M., Bentler, "Cutoff criteria for fit indexes in covariance structure analysis: Conventional criteria versus new alternatives," Structural equation modeling: a multidisciplinary J., vol. 6, no. 1, pp. 1-55, Jan. 1999.

[39] M. W., Browne, "Alternative ways of assessing model fit," Testing structural equation models, 1993.

[40] P. M., Bentler, and D. G. Bonett, "Significance tests and goodness of fit in the analysis of covariance structures," Psychological bulletin, vol, 88, no. 3, pp. 588, 1980.

[41] B. G., Tabachnick, L. S., Fidell, and J. B. Ullman, "Using multivariate statistics," Boston, MA: Pearson, vol. 5, pp. 481-498, 2007.

[42] T. A., Brown, Confirmatory factor analysis for applied Res. Guilford publications, 2015.

[43] R. B., Kline Principles and practice of structural equation modeling. Guilford publications, 2015. 